Supporting information for:

\title{
Harvesting energy from salinity differences using battery electrodes in a concentration flow cell
}

\author{
Taeyoung Kim, ${ }^{\mathrm{a}}$ Mohammad Rahimi, ${ }^{\mathrm{b}}$ Bruce E. Logan, ${ }^{\mathrm{a}}$ and Christopher A. Gorski*a \\ ${ }^{a}$ Department of Civil and Environmental Engineering, The Pennsylvania State University, \\ University Park, PA 16802, USA \\ ${ }^{b}$ Department of Chemical Engineering, The Pennsylvania State University, \\ University Park, PA 16802, USA \\ *Corresponding Author, gorski@engr.psu.edu; \\ +1-814-865-5673 (phone), +1-814-863-7304 (Fax)
}

The supporting information contains 8 figures and 16 pages.

A. Evaluating internal resistance of the flow cell ......................................................... 2

B. Evaluating area resistance of membrane using a DC current method.................................. 4

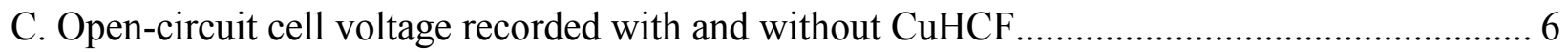

D. Estimation of cell voltage development based on activity coefficients ............................. 8

E. Electrochemical characterizations of CuHCF electrode................................................. 10

F. Cell voltage profiles depending on external resistance values ........................................ 12

G. Area resistance of membrane as a function of $\mathrm{NaCl}$ concentration ..................................... 13

$\mathrm{H}$. Irreversible mixing of $\mathrm{NaCl}$ solutions across the filtration membrane in the flow cell .......... 14

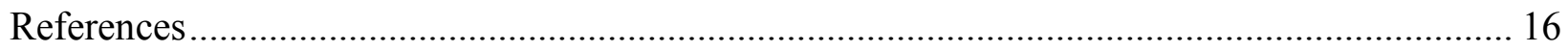




\section{A. Evaluating internal resistance of the flow cell}

Internal resistance of the flow cell was examined by measuring voltage drop when applying constant current. Experiments were conducted by varying combinations of high (HC, $0.513 \mathrm{M}$ $\mathrm{NaCl}$ ) and low concentration (LC, $0.017 \mathrm{M} \mathrm{NaCl}$ ) feed solutions: HC+LC, HC+HC, and LC+LC. Feed solutions were continuously supplied to each chamber of the flow cell during the experiments. The flow cell first equilibrated by applying $0 \mathrm{~V}$ for $5 \mathrm{~min}$, and the circuit was opened for $1 \mathrm{~min}$. Then, $0.5 \mathrm{~mA}$ was applied until the cell voltage approached to $0.03 \mathrm{~V}$. Next, the cell voltage was set to $0.03 \mathrm{~V}$ for $5 \mathrm{~min}$ followed by open circuit, and discharged by applying $-0.5 \mathrm{~mA}$ until $0 \mathrm{~V}$. The voltage drop was taken from the linear fit of charging or discharging profiles after the constant slope was achieved (typically in $30 \mathrm{sec}$, Fig. S1). 


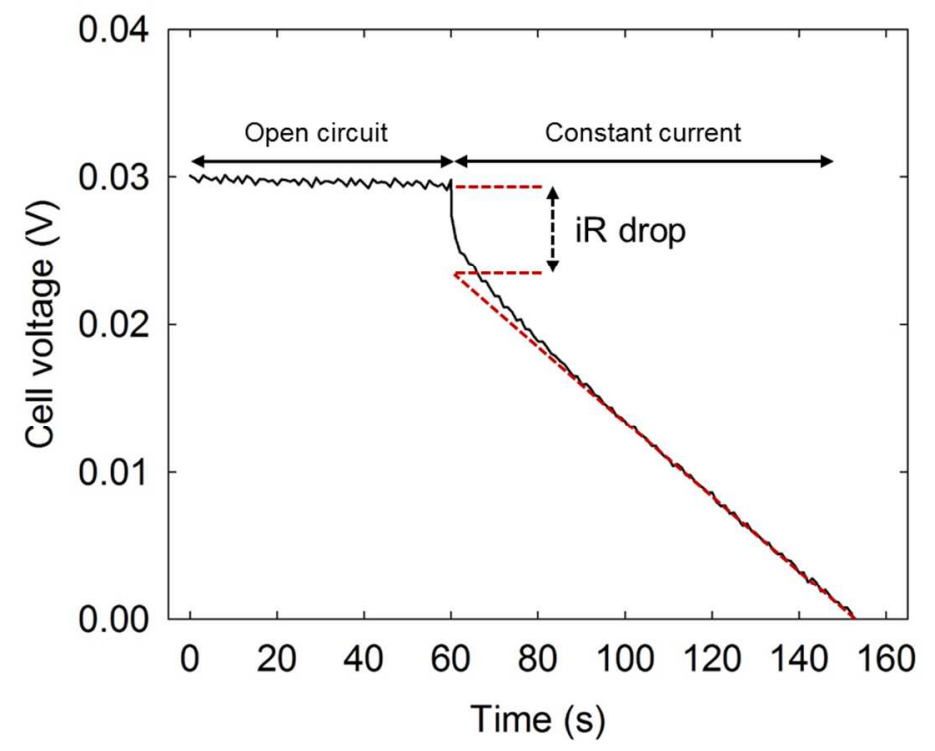

Figure S1. Representative voltage profile for obtaining internal resistance of the flow cell by applying constant current $(-0.5 \mathrm{~mA})$. 


\section{B. Evaluating area resistance of membrane using a DC current method}

Area resistance of membrane was measured using a DC current method. ${ }^{1}$ A membrane was placed between two chambers (each $4 \mathrm{~cm}$ long, $3 \mathrm{~cm}$ in diameter, inner volume $=\sim 30 \mathrm{ml}$ ), where platinum mesh and $\mathrm{Ag} / \mathrm{AgCl}$ reference electrodes were installed (Fig. S2a). Reference electrodes were placed close to a membrane $(2.7 \mathrm{~cm}$ apart $)$ and platinum mesh electrodes were placed at each end of chamber ( $7.8 \mathrm{~cm}$ apart). After filling the chambers with the solution, constant current was applied (1-10 mA) to platinum electrodes while the voltage between reference electrodes were recorded using a potentiostat (VMP3, Bio-Logic). The resistance was calculated from the slope of current and voltage $(\mathrm{R}=\mathrm{V} / \mathrm{I})$. The resistance was first measured without a membrane, which is the background resistance mainly due to the solution, and this value was subtracted from the resistance measured with a membrane (Fig. S2b). The area resistance was then calculated by multiplying area of the membrane $\left(7.07 \mathrm{~cm}^{2}\right)$. All experiments were performed in triplicated at room temperature. 
(a)

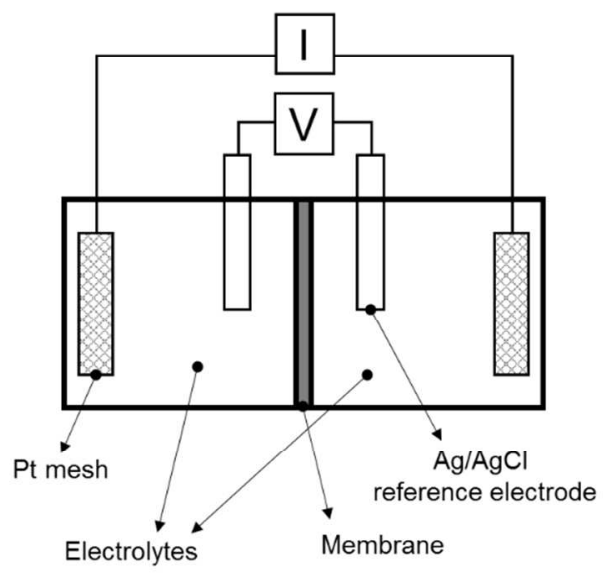

(b)

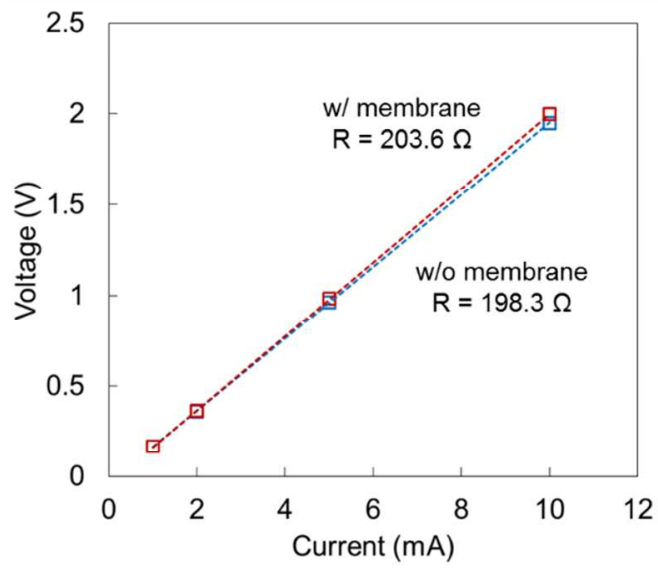

Figure S2. (a) A custom-built reactor for measuring area resistance of membrane and (b) representative voltage vs. current plot measured w/ and w/o membrane in $0.017 \mathrm{M} \mathrm{NaCl}$. 


\section{Open-circuit cell voltage recorded with and without $\mathrm{CuHCF}$}

To examine the cell voltage development of the flow cell without $\mathrm{CuHCF}$, open-circuit cell voltage profiles were obtained using graphite foil without CuHCF (Fig. S3). In the regular operating condition (with $\mathrm{CuHCF}$ in 0.017 and $0.513 \mathrm{M} \mathrm{NaCl}$, black rectangles), open-circuit cell voltage achieved was approximately $172 \mathrm{mV}$. The cell voltage of approximately $20 \mathrm{mV}$ was recorded without $\mathrm{CuHCF}$ (white rectangles), which can be ascribed to the liquid junction potential. The configuration of the flow cell, high and low concentration $\mathrm{NaCl}$ solutions separated by a membrane, can enable the diffusion of ions in the high concentration solution into the low concentration solution through the membrane. Since $\mathrm{Cl}^{-}$diffuses faster than $\mathrm{Na}^{+}$, more positive potential could be developed in the channel filled with high concentration $\mathrm{NaCl}$. To better understand this additional potential, the open-circuit cell voltage was measured using $\mathrm{KCl}$, which has similar cation and anion diffusion rate (grey rectangles). The cell voltage measured was approximately $15 \mathrm{mV}$, which was comparable to that of $\mathrm{NaCl}$. Thus, the additional cell voltage cannot be explained only by different diffusion rate of $\mathrm{Na}^{+}$and $\mathrm{Cl}^{-}$. A few functional groups of the filtration membrane may facilitate the diffusion of $\mathrm{Cl}^{-}$and/or impede that of $\mathrm{Na}^{+}$. 


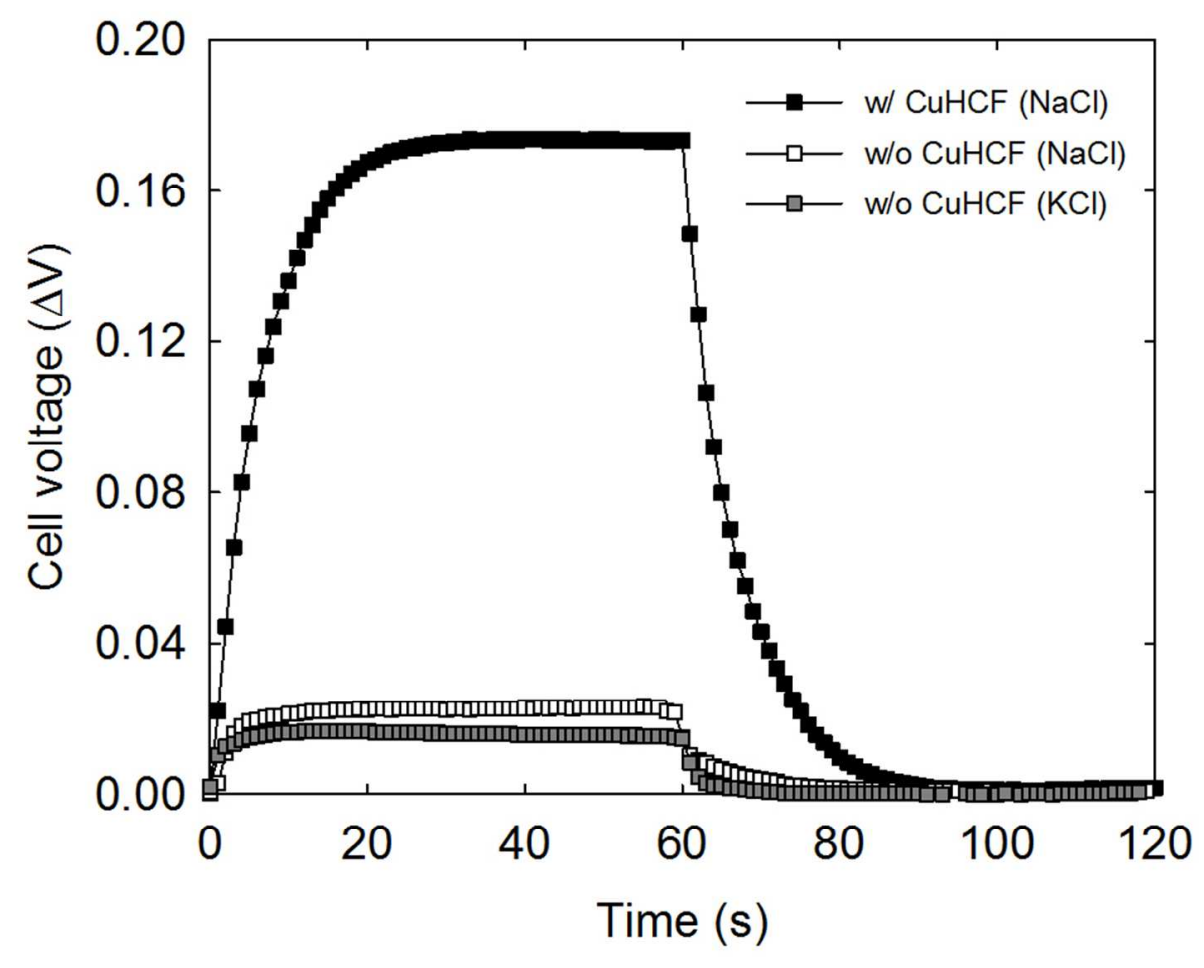

Figure S3. Open-circuit cell voltage profiles recorded $\mathrm{w} / \mathrm{CuHCF}$ in $\mathrm{NaCl}$ (black rectangles), w/o CuHCF in $\mathrm{NaCl}$ (white rectangles), and w/o CuHCF in $\mathrm{KCl}$ (grey rectangles). 


\section{Estimation of cell voltage development based on activity coefficients}

The activity-dependent electrode potential can be estimated from the following Nernst equation:

$$
E=E^{0}+\frac{R T}{F} \ln \left[a_{N a^{+}}\right]
$$

where $E$ is the electrode potential, $E^{0}$ is the standard electrode potential, $R$ is the gas constant $\left(8.314 \mathrm{~J} \mathrm{~mol}^{-1} \mathrm{~K}^{-1}\right), T$ is temperature $(\mathrm{K}), F$ is the Faraday constant $\left(96,485 \mathrm{C} \mathrm{mol}^{-1}\right)$, and $a$ is activity. In the flow cell, two CuHCF electrodes were simultaneously exposed to HC and LC solutions, and therefore the cell voltage difference $(\Delta U)$ can be written as:

$$
\Delta U=2 \frac{R T}{F} \ln \left[\frac{a_{N a_{H C}^{+}}}{a_{N a_{L C}^{+}}}\right]
$$

The concentration-dependent cell voltage development of this flow cell was estimated based on reported mean activity coefficient values of $\mathrm{NaCl}$ solutions $\left(0.01-1.00 \mathrm{~mol} \mathrm{~kg}^{-1}\right.$ at $\left.25^{\circ} \mathrm{C}\right) .{ }^{2}$ The molality values were converted to molarity, and the arbitrary electrode potential was plotted vs. $\mathrm{NaCl}$ concentrations (M) by following Nernst equation,

$$
E=E^{0}+\frac{R T}{F} \ln \left(\gamma_{ \pm N a C l} c\right)
$$

where $\gamma_{ \pm \mathrm{NaCl}}$ is the mean activity coefficient of $\mathrm{NaCl}$, and $c$ is the concentration. Estimated electrode potential difference between 0.017 and $0.513 \mathrm{M} \mathrm{NaCl}$ was approximately $81 \mathrm{mV}$ (Fig. S4), which becomes $162 \mathrm{mV}$ in the flow cell. 


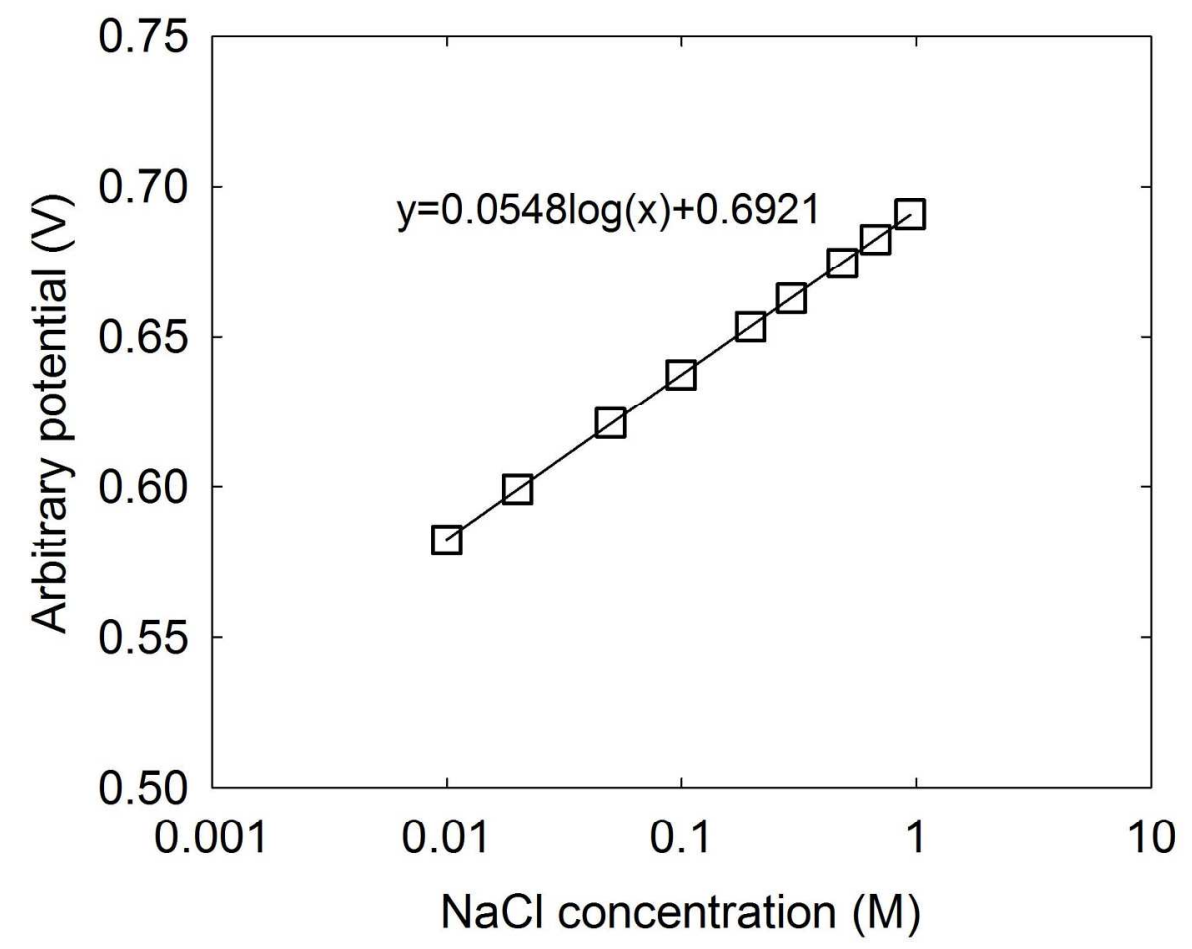

Figure S4. Arbitrary potential vs. concentration plot derived from mean activity coefficient values of $\mathrm{NaCl}$. 


\section{E. Electrochemical characterizations of CuHCF electrode}

Cyclic voltammetry was conducted by using CuHCF electrode painted on Ti foil using a brush. Representative cyclic voltammogram was obtained in $1 \mathrm{M} \mathrm{NaCl}$ at a scan rate of $1 \mathrm{mV} \mathrm{s}^{-1}$ (Fig. $\mathrm{S} 5 \mathrm{a})$. Note that small electrode material loading $(\sim 1 \mathrm{mg})$ could have resulted in inaccurate mass based current $(\mathrm{A} / \mathrm{g})$. Galvanostatic cycling test was performed by using $\mathrm{CuHCF}$ coated on graphite foil in a half-cell consisting of $\mathrm{Ag} / \mathrm{AgCl}$ reference electrode and activated carbon (YP50F) counter electrode, and $0.513 \mathrm{M} \mathrm{NaCl}$ was used as an electrolyte (Fig. S5b). The cell was charged and discharged at $\pm 3 \mathrm{~mA}$ in the range of $0.6-0.8 \mathrm{~V}$ (vs. $\mathrm{Ag} / \mathrm{AgCl}$ ) for 50 cycles, and the resulting discharging capacity and coulombic efficiency were calculated. After 50 cycles, the capacity retention was 99\% and coulombic efficiency was 99.5\% (Fig. S5c). When performed galvanostatic charge/discharge tests in the flow cell by applying $\pm 0.5 \mathrm{~mA}(0.0-0.05 \mathrm{~V})$, the coulombic efficiency was $76 \%$ when flowing $\mathrm{HC}(0.513 \mathrm{M} \mathrm{NaCl})$ and $\mathrm{LC}(0.017 \mathrm{M} \mathrm{NaCl})$, and $89 \%$ when flowing HC and HC (Fig. S5d). Since the power production in the flow cell was achieved by discharging only, these coulombic efficiency values would not represent the efficiency of the flow cell. 
(a)

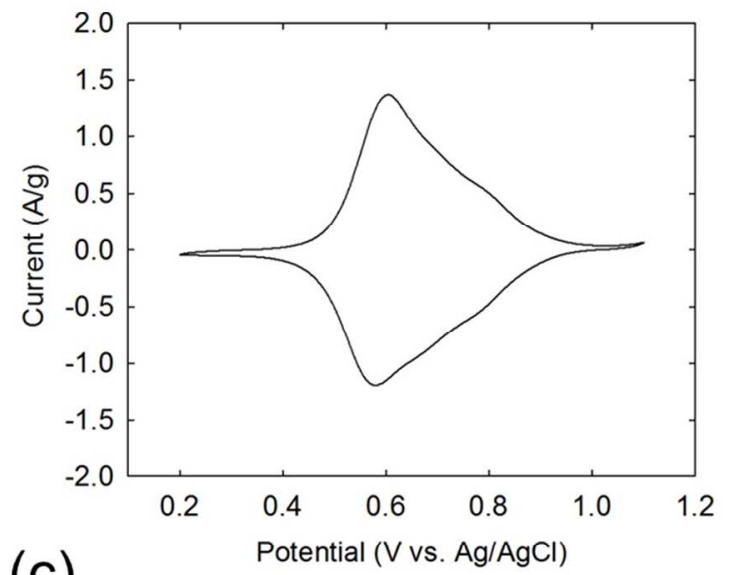

(c)

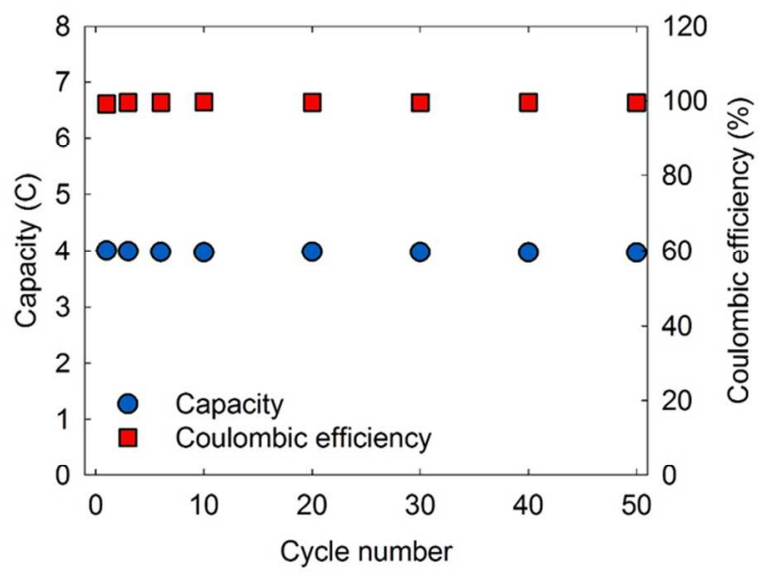

(b)

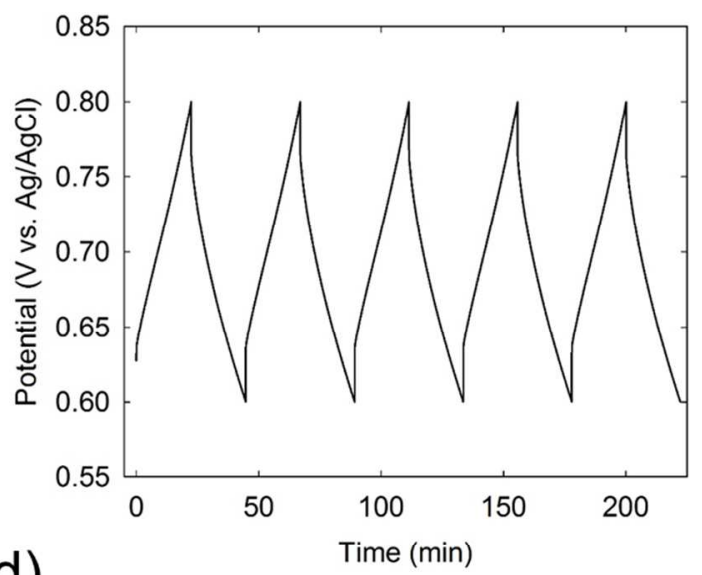

(d)

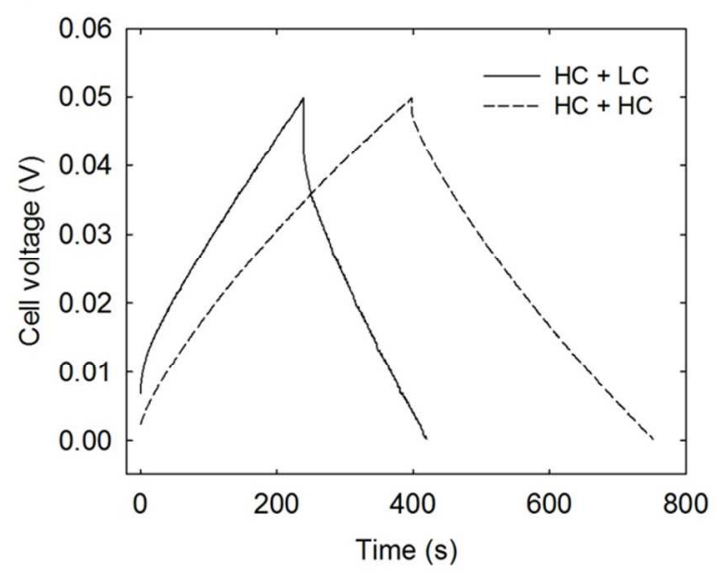

Figure S5. (a) Cyclic voltammogram of CuHCF in $1 \mathrm{M} \mathrm{NaCl}$ at a scan rate of $1 \mathrm{mV} \mathrm{s}^{-1}$. (b) Representative galvanostatic charge/discharge profiles at $\pm 3 \mathrm{~mA}(0.6-0.8 \mathrm{~V})$ in $0.513 \mathrm{M} \mathrm{NaCl}$, (c) capacity and coulombic efficiency for 50 cycles, and (d) galvanostatic charge/discharge profiles recorded in a flow cell by applying $\pm 0.5 \mathrm{~mA}(0.0-0.05 \mathrm{~V})$ while flowing $\mathrm{HC}(0.513 \mathrm{M}$ $\mathrm{NaCl})$ and $\mathrm{LC}(0.017 \mathrm{M} \mathrm{NaCl})$ or $\mathrm{HC}$ and $\mathrm{HC}$ solutions through each channel at the flow rate of

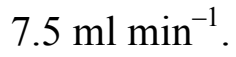


F. Cell voltage profiles depending on external resistance values

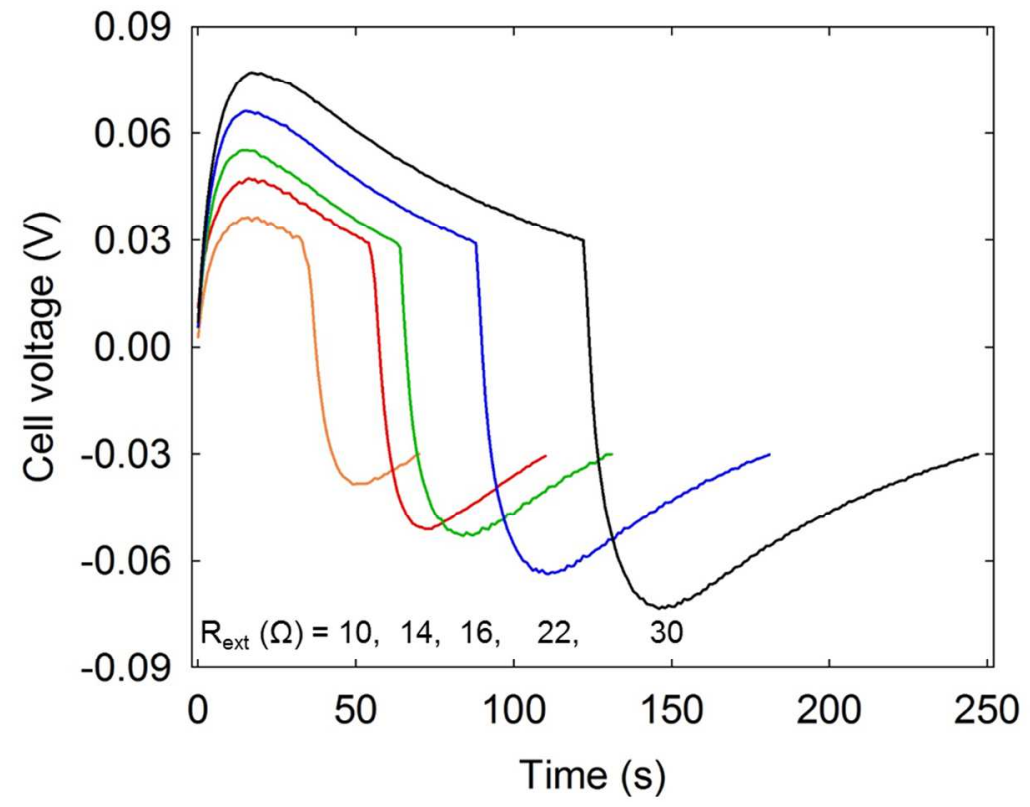

Figure S6. Representative voltage profiles depending on external resistance $(10,14,16,22,30$ $\Omega)$. 


\section{G. Area resistance of membrane as a function of $\mathrm{NaCl}$ concentration}

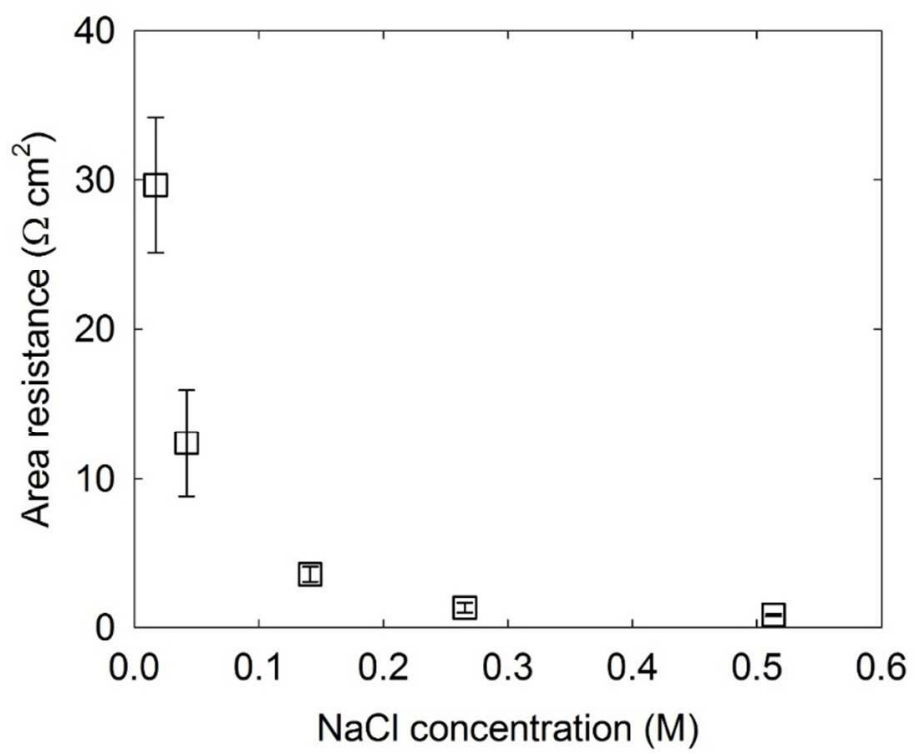

Figure S7. Area resistance of membrane (MSI) as a function of $\mathrm{NaCl}$ concentration $(0.017$, $0.042,0.141,0.265,0.513 \mathrm{M})$. 


\section{H. Irreversible mixing of $\mathrm{NaCl}$ solutions across the filtration membrane in the flow cell}

To examine the irreversible mixing of high and low concentration $\mathrm{NaCl}$ solutions across the filtration membrane (magna nylon, thickness $=110 \mu \mathrm{m}$, pore size $=0.22 \mu \mathrm{m}$, Micron Separations Inc.), we recorded the conductivities of high and low concentration solutions (HC and LC) in the reservoir (each $100 \mathrm{~mL}$ ) while flowing two solutions through each channel of the flow cell $($ channel width $=1 \mathrm{~cm}$; height $=3 \mathrm{~cm}$; thickness $=400 \mu \mathrm{m})$ at the flow rate of $7.5 \mathrm{ml} \mathrm{m^{-1 }}$ without electrodes. After flowing the solutions for $100 \mathrm{~min}$, the conductivity of HC decreased from 47.8 to $45.9 \mathrm{mS} \mathrm{cm}^{-1}$, while that of $\mathrm{LC}$ increased from 1.98 to $3.76 \mathrm{mS} \mathrm{cm}^{-1}$ (Fig. S8). The $\mathrm{HC} / \mathrm{LC}$ ratio, which can be converted to the cell voltage in the flow cell, decreased from 24.1 to 12.2 , indicating that approximately $35 \mathrm{mV}$ of the cell voltage would be lost due to the irreversible mixing. The average crossover flux evaluated from the initial and final conductivity values of LC was $0.87 \mathrm{mmol} \mathrm{m}^{-2} \mathrm{~s}^{-1}$ for the $100 \mathrm{~min}$. The mixing would be affected by various parameters such as membrane porosity, channel dimensions, and hydraulic retention time. 


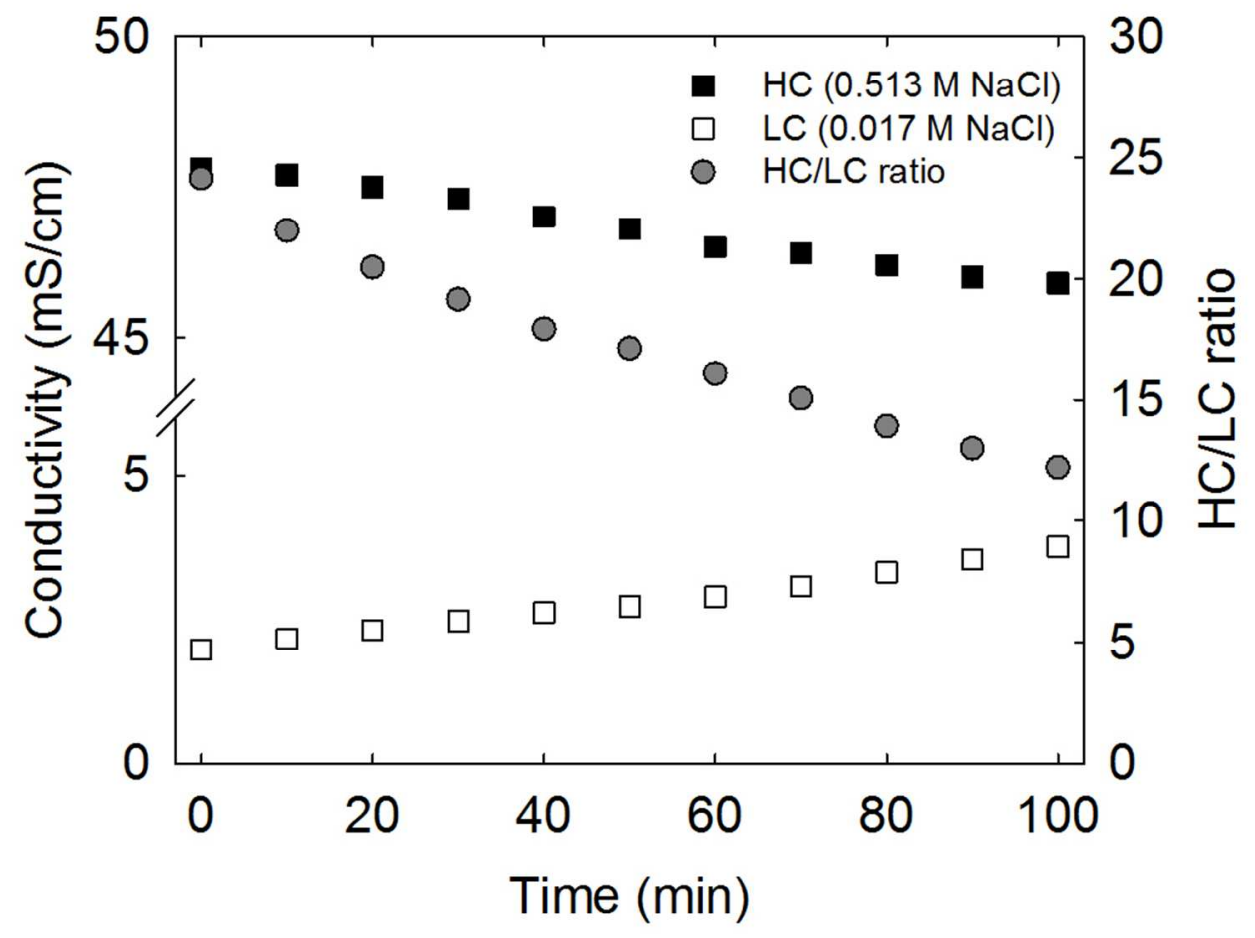

Figure S8. Conductivity values of $\mathrm{HC}$ (filled squares, $0.513 \mathrm{M} \mathrm{NaCl}$ ) and LC (open squares, $0.017 \mathrm{M} \mathrm{NaCl}$ ) and $\mathrm{HC} / \mathrm{LC}$ ratio (gray circles) as a function of time. 


\section{References}

1. G. M. Geise, A. J. Curtis, M. C. Hatzell, M. A. Hickner and B. E. Logan, Environ. Sci. Technol. Lett., 2013, 1, 36-39.

2. A. H. Truesdell, Science, 1968, 161, 884-886. 